\title{
Sexual Partner
}

National Cancer Institute

\section{Source}

National Cancer Institute. Sexual Partner. NCI Thesaurus. Code C100812.

A person with whom one has had sexual relations. 